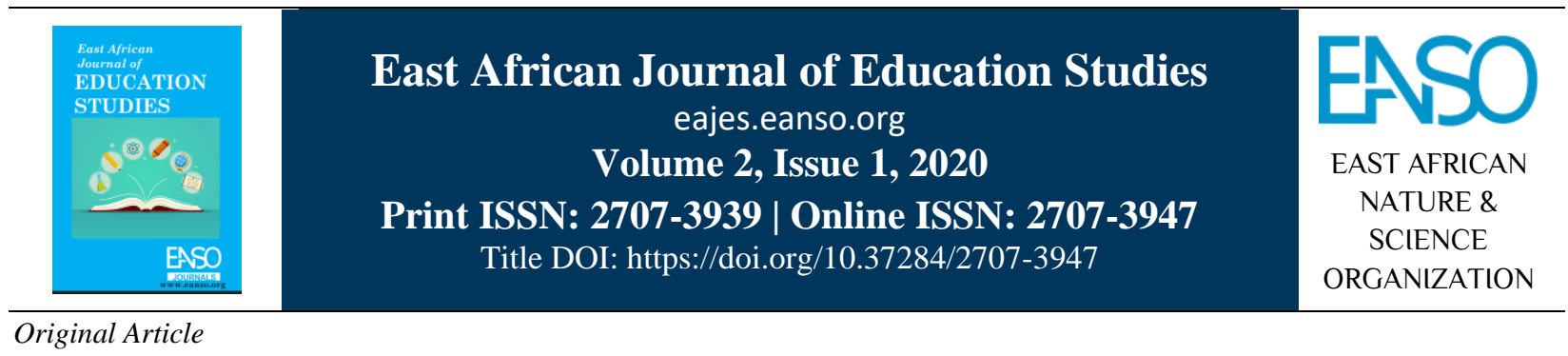

\title{
Family Background and Its Effect on Pupils' Transition Rate from Primary to Secondary Schools in Soin/Sigowet Sub-County, Kenya
}

\author{
Stanley Langat Kimutai ${ }^{1 *} \&$ Dr. Stephen Tomno Cheboi ${ }^{1}$ \\ ${ }^{1}$ School of Education, Mount Kenya University, P. O Box 1902 - 20200, Kericho, Kenya. \\ *Author for Correspondence Email: stanleylangat35@gmail.com.
}

Article DOI: https://doi.org/10.37284/eajes.2.1.180

Date Published: ABSTRACT

10 June 2020 The purpose of this study was to establish the effect of pupils' family backgrounds on their transition rates from public primary schools to secondary

Keywords: schools in Kenya's Soin/Sigowet Sub-County. The study adopted mixed

Family Background, methods approach and the research design employed was descriptive survey. It Rates of Transition,

Public Primary, Secondary Schools. targeted a population of 76 headteachers and 715 teachers from which a sample of 63 headteachers and 250 teachers was used. Clustered random sampling was used to obtain the 63 schools from their zones, simple random sampling to select teachers and purposive sampling on headteachers. Structured questionnaires were used to collect data from teachers and interview schedule from headteachers. The two instruments were validated, piloted and a reliable 0.75 Cronbach's coefficient alpha applied. Quantitative data was analysed and presented in frequencies and percentages, while qualitative data was described alongside the quantitative data. The key findings of this study were: educated parents provided moral and material support to their children, occupation of parents determined their financial ability to educate their children and parental involvement played a crucial role in the performance and progress of their children in education. The study revealed that family challenges which included homelessness, hunger, domestic violence and drug abuse affected the transition of pupils from public primary to secondary schools. The study recommended that education stakeholders in the Sub-County should sensitize parents on the importance of ensuring children proceed from one level of education to another. On further research, the study recommended that the research needed to be replicated in other parts of the country by varying its approach. 


\section{APA CITATION}

Kimutai, S., \& Cheboi, S. (2020). Family Background and Its Effect on Pupils' Transition Rate from Primary to Secondary Schools in Soin/Sigowet Sub-County, Kenya. East African Journal of Education Studies, 2(1), 78-85. https://doi.org/10.37284/eajes.2.1.180.

\section{CHICAGO CITATION}

Kimutai, Stanley, and Stephen Cheboi. 2020. "Family Background and Its Effect on Pupils' Transition Rate from Primary to Secondary Schools in Soin/Sigowet Sub-County, Kenya”. East African Journal of Education Studies 2 (1), 78-85. https://doi.org/10.37284/eajes.2.1.180.

\section{HARVARD CITATION}

Kimutai, S. and Cheboi, S. (2020) "Family Background and Its Effect on Pupils' Transition Rate from Primary to Secondary Schools in Soin/Sigowet Sub-County, Kenya", East African Journal of Education Studies, 2(1), pp. 78-85. doi: 10.37284/eajes.2.1.180.

\section{IEEE CITATION}

S. Kimutai, and S. Cheboi, "Family Background and Its Effect on Pupils' Transition Rate from Primary to Secondary Schools in Soin/Sigowet Sub-County, Kenya”, EAJES, vol. 2, no. 1, pp. 78-85, Jul. 2020.

\section{MLA CITATION}

Kimutai, Stanley, and Stephen Cheboi. "Family Background and Its Effect on Pupils' Transition Rate from Primary to Secondary Schools in Soin/Sigowet Sub-County, Kenya”. East African Journal of Education Studies, Vol. 2, no. 1, Jul. 2020, pp. 78-85, doi:10.37284/eajes.2.1.180.

\section{INTRODUCTION}

In related studies, family background affects the transition of pupils from primary to secondary schools both in developed and developing countries (Chimombo, 2009; Fredrick, 2011 and Ogola, 2013). Transition rate to secondary schools in developed countries is above the global average but most developing countries, especially in Eastern, Southern, Western, Central Africa, have transition rate of below the global average of $85 \%$ (UNESCO Institute of statistics, 2014). The levels of transition include from home to preschools, from preschools to primary schools, from primary to secondary schools, from secondary schools to colleges (Kaburu, 2013).

Parents' education level, their occupation and their involvement in education either directly or indirectly affect the transition of children from one level of education to another. This is because early educational decisions are heavily influenced by parental background. The observation concurred with Onyango (2013) who observed that bettereducated parents value their children's progress with education, both morally and materially more than illiterate ones. Educated parents act as role models to their children, who look up to and emulate them (Okuogo, 2013), and therefore motivate them to aim and transit to higher levels unlike parents with little or no education who are not aware of the benefits of education. They guide their children to pursue relevant courses which enable them secure jobs thus their children are motivated to proceed in their studies. Schooling level of parents, their involvement in the education of their children, their occupation and birth order in families directly or indirectly affect the movement of children from one level of education to another (Onyango, 2013). Children's capacity to succeed depends on the successful guidance of their parents as children interact with their surroundings and acquire skills, knowledge and attitude contributed by the environment (Vellymalay, 2012). According to Kikechi and Geoffrey (2011) children who are closely monitored, regulated and given emotional support dedicate their time to their studies and seldom terminate their studies at early levels. They encourage them to pick-up when they get are demoralized due to poor performance unlike parents who lack interest in educating their children and therefore talk ill about education thus discourage their children thereby may drop out school, fail to complete primary or transit to secondary school (Bynes and Balfanz, 2012). Parents who closely monitor and motivate their children give them morale to pursue their studies.

Parental influence, therefore, determines how children value education and desire to pursue from one level to another. The occupation of parents creates inequality in society because they vary in 
prestige. Some have access to higher occupation status. Differences in occupations of parents have a direct impact on the education of their children thus influence their transition from one level of education to another. The level of power to control community resources determines the ability to educate children and expose them to available job opportunities in the society. Professionals like teachers, doctors, bankers and engineers in the community have a different upbringing of their children from those of farmers and domestic workers (Byrnes \& Balfanz, 2012). Parents want their children to succeed in life, therefore, influences their career development. Since they are the first people to network with children, they are regarded as primary determinants of children's social class. Family network and their composition constitute a greater percentage to transition from primary to secondary schools while family challenges are contributing factors to school dropouts and by extension failure to transit from primary to secondary schools (Kaburu, 2013). When parents possess the resources and skills, they apply them efficiently for the upbringing of their children for the benefit of the entire society (Madassir, 2015). Parents' socio-economic status plays a significant role in providing educational resources which impose a bigger impact on the child's educational outcomes. Secondary education requires more specialized infrastructure and equipment for laboratories and libraries. In most countries where parents meet the cost of education, state investment in secondary education tends to be the most neglected of the education sector receiving an average of $15 \%$ to $20 \%$ of the total education resources from the government (World Bank, 2008). Since the start of free primary education in 2003 in Kenya, the number of primary school children increased by $18 \%$ from $6,063,000$ to $7,160,000$ which has increase pressure on the government and households on the cost of education for learners who transited to secondary schools (Ogola 2013).

Parents do not afford to pay tuition and maintenance fee which has made their children stay away from school and instead spent their time contributing to the family's income. This makes them ill-prepared for learning. The poor transition for children from low-income families is worsened by the high cost of education in secondary schools.
Most public primary schools use unbranded uniform which is affordable to many parents while secondary schools emphasize branded uniforms raising the cost of education thus contributing to the poor transition from primary to secondary schools. The situation is worsened by administrators of secondary schools who direct purchase of uniform from a single outlet thus creating monopoly instead of using a range of suppliers (Alderman, 2009). Parents who are well paid in their occupation provide their children with all the requirements in schools and promotes their education. Children whose parents are poorly paid in their occupation do not get humble time to study at school and at home thus perform poorly in their academic work since their parents are struggling to meet family basic needs and so pay little attention to their education (Charles, 2013). Cost-effective supplementary learning and teaching materials can enrich learning and improve students' outcomes at all levels and across disciplines by increasing student engagement and providing learners several ways of demonstrating their knowledge and skills (UNESCO, 2014). However, the high cost of supplementary materials hinders pupils from transiting to secondary schools after completing primary education (Dominic, 2013). Parental occupation creates inequality in financial positions of families thus determine the capability of parents to provide their offspring with supplementary learning materials, fare to schools, tuition fee and cost of uniforms. Financial constraints, therefore, hinder parents from investing in their children which culminate to poor education and low transition to higher levels of education. Schools in marginalized and rural areas are few and far from one another and this limits the access by learners who do not have transport options. Therefore, students trek long distances to school due to high transport fairs on the few available means of transport (UNICEF, 2016). The lengthy footing children to school disorganize their concentration in class because they get exhausted both physically and psychologically. This, therefore, put much pressure on their parents to meet the transport cost of their children to and from school. Situations whereby parents are not able to raise the amount, a learner feel demoralized and may drop out of school. 


\section{Statement of the Problem}

Low transition rates of pupils from primary to secondary schools in Kenya over the years have been a major concern to all stakeholders. In 2016, of the 927,789 pupils who sat for the 2015 Kenya Certificate of Primary Examination, 167,000 (18\%) pupils were not admitted to secondary schools (MOE,2018). The government of Kenya has continuously improved education access through curriculum reforms and reviews, infrastructural upgrading at primary, secondary and teachers' training colleges (MOE, 2018). However, these efforts have not translated to $100 \%$ transition as envisaged by the government policy in from primary schools in Kenya and particularly in Soin/Sigowet Sub-County which had an average of $89 \%$ transited to secondary schools between 2014 and 2018. Several social correlates such as cultural factors, pupils' attitudes, family background and background of the community are blamed for this state of affair. The study, therefore, sought to establish the effect of pupils' family background on their transition from primary to secondary schools in Soin/Sigowet Sub-County.

\section{MATERIALS AND METHODS}

This study employed mixed-method approach that used both quantitative and qualitative methods of inquiry and adopted a descriptive survey research design that is most appropriate to study a large population using a sample. According to Creswell (2009), mixed-methods approach brings a connection of pragmatic theoretical worldviews, strategies of inquiry as well as research methods into the study. According to Tomno (2014), this approach was meant to triangulate the findings obtained from questionnaires and interview schedule to give a clear understanding of the research problem. Descriptive survey design is a way of collecting information through interviews and giving questionnaires to be filled by a given sample of people (Orodho, 2009). The appropriateness of the research methods was because it allowed the researcher to collect firsthand information from respondents who witnessed occurrences in the selected areas (Dermir, 2009).
This study engaged a population of 791 comprising 76 head teachers and 715 teachers from all the 76 public primary schools in Soin/Sigowet SubCounty. Using Krejcie \& Morgan (1970) table of determining sample size, 63 head teachers and 250 teachers were sampled from 6 educational zones. A structured questionnaire was used to collect quantitative data from the sampled teachers while qualitative data from the headteachers was collected using an unstructured interview guide. The two instruments were used since more than one instrument gives a clear understanding of the problem at hand. The instruments were validated appropriately to collect what it was supposed to measure. To establish the reliability of the instruments they were piloted on respondents that did not participate in the study and a reliable Cronbach's coefficient alpha 0.75 was obtained after computing the pilot data. The questionnaires were issued to the teachers by the researcher and collected after an agreed time to avoid contamination of the data. The researcher then interviewed the headteacher to obtain qualitative data. Quantitative data was analyzed to obtain frequencies and percentage while qualitative data was cleaned and categorized into themes in line with the objective.

\section{FINDINGS AND DISCUSSIONS}

The study sought to establish how the family background of pupils affects their rates of transition from public primary to secondary schools in Soin/Sigowet Sub County, Kenya. Specifically, on whether educated parents provide moral and material support more than illiterate parents, the following findings were obtained; That 243 (97\%) teachers agreed while 7 (3\%) of them believed that all parents provided moral and material support to their children regardless of the education level. This corroborates the findings of Onyango (2013) that educated parents value their children progress with education both morally and materially. The high percentage of teachers who agreed that education level of parent influence progress of a learner, supports the observation made by Vallymaley (2012) that children's capacity to proceed depends on the successful guidance of their parents being determined by their education level. 
On their part headteachers observed that education of parents influences the education of their children since they emulate them, being the immediate role models in the society. They also argued that educated parents employed good parenting skills, provide a good learning environment and good learning opportunities to their children. Their argument concurred with the research findings by Dalton and Glauber (2019) who observed that professionals like, doctors, teachers and engineers have different upbringing of their children from those of farmers and domestic workers. The headteachers generally observed that this enables their children to perform well academically thus enabling them to proceed to the next level of education. Headteachers further added that educated parents are aware of the needs of schoolgoing children and since they have resources and understand requirements for success and value of education, they avail school requirement to their children for smooth learning to take place.

On whether family problems which include homelessness, hunger, domestic violence and drug abuse reduce the number of pupils transiting to secondary schools in Soin/Sigowet Sub County, the following findings were obtained; 230 (92\%) teachers agreed that they affect the transition from public primary to secondary schools. Twenty $(8 \%)$ of them did not believe that the above family challenges affect pupils' transition to secondary schools. These high numbers of respondents (230) who believe that homelessness, hunger, domestic violence and drug abuse negatively affect the transition of pupils from public primary to secondary schools prove that they are part of family correlates which lower pupils' transition rates to secondary schools.

On how the occupation of parents affects the transition of pupils to secondary schools; the researcher established from respondents that occupation determines the financial ability of parents in that those who are in well-paying occupations, finances their children to join secondary schools of their choices thus motivate their children, enabling them to achieve a high rate of transition to secondary schools. Respondents argued that enlighten parents seek education for their children and provide basic needs since salary is not affected by climatic conditions as in farming and manual work. The response concurs with Byrnes and Balfanz (2012) who observed that the financial position of families created by occupation determines the capacity of parents to provide their children with the required learning materials. Responds also added that parents whose occupations do not generate good income are not able to meet basic needs and school requirement for their children; hence their children are frequently disturbed in schools. They are also not able to take their children to high-cost schools which demoralize pupils lowering rates of transition to secondary schools. The headteachers attributed this to the fact that they are subsistence farmers. Other respondents argued that parents neglected their children since they did not have time to advise, monitor and motivate them in studies which lead to high dropouts. They noted that the distance of parents from their children due to the nature of their occupations give room to children to associate with people of undesirable character. They added that occupations such as the brewing of alcohol, prostitution and drug trafficking influence children to go the same way leading to poor transition.

It was also reported that successful parents who are not educated affect learners' education negatively since pupils admire how these people generate their income away from professional occupations. On the other hand, they said that people with prestigious occupations act as role models to their children, therefore children look upon them as they pursue their studies. According to corresponds, educated parents guide their children to well-paying occupation since occupation leads to different parenting skills. Their children are motivated to learn, transit to secondary schools and to higher learning institutions in order to secure them wellpaying occupations. This concurred with Shafiqul (2015) who observed that children's capacity to succeed depend on the successful guidance from their parents.

As regards the effect of parental involvement on the performance of pupils and their transition to secondary schools, respondents observed that friendly and concerned parents make their children pay attention to their advice and enable them to express themselves freely and share their challenges with them. This they said creates a good learning atmosphere for children enabling them to 
perform well and transit to secondary level. This agrees with Lewin (2008) who argued that parental engagement in children's activities enhances positive academic mobility, children whose parents are actively involved in their education perform well. Concerned parents give their children moral support and time to study. They also provide their children with materials and financial support. If parents do not provide proper follow-up on daily activities undertaken by their children, it leads to poor transition to secondary schools. On teachers' response on the effects of parental involvement on pupils' progress in education and their transition from primary to secondary schools, 132 (53\%) teachers agreed that parents in their schools are concerned on the progress of their children while $118(47 \%)$ argued that parents are not actively concerned. This indicates that parents who follow up on the progress and performance of their children in schools are slightly above average. $47 \%$ of parents who were not actively concerned with the educational progress of their children contributed greatly to the poor transition of the children to secondary schools. This finding concurred with Kaburu (2013) who stated that lack of parental involvement in pupils' progress in education is a barrier in the transition from primary to secondary education.

When asked whether the size of a family is a challenge to parent in meeting the cost of educating their children, 232 (93\%) respondents believed that it hinders parents from meeting the cost of education while $18(7 \%)$ believed that size of a family is not a challenge. According to the respondent, large families in the Sub County as a result of illiteracy and lack of exposure by parents on ways of family planning was a challenge to most families in meeting the cost of education of their children which then leads to school dropout and poor transition to secondary schools. This agrees with Dalton and Glauber (2009) who observed that there is a negative relation between child quantity and child quality. They added that this contributes greatly to the inability of the parents to meet tuition and maintenance fee of their children and consequently, their children stay away from school therefore they are ill-prepared for learning.

\section{CONCLUSIONS}

The following conclusions were drawn on the findings of the study;

The findings revealed that there are family-related challenges which include the education level of parents, parental occupation and parental involvement which lower the transition rates. Other challenges identified include drug abuse by parents, domestic violence and separation of parents. Family size is not a major challenge in relation to family background unless the family has economic problems. There is high transition in families with high education level where parents are professionals and are actively involved in the education of their children. Low transition to secondary schools is mainly found in families with low education level, where parents are casual labourers or peasant farmers and those whose parents are less concerned with the education of their children.

\section{RECOMMENDATIONS FOR PRACTICE}

Sub-County director of education in collaboration with headteachers and other education stakeholders need to sanitize parents on the importance of ensuring that their children proceed from one level of education to another so as to compete fairly for competitive job opportunities. This will enable them to change the status of the families and help their parents who may not have gotten the opportunity to get quality education. The study recommends that headteachers should organize for teachers' and parents' meeting whereby educated parents will interact with other parents with little or no education and discuss ways of providing moral and material support to pupils. Children who undergo family challenges to be supported by all school stakeholders.

\section{RECOMMENDATIONS FOR FURTHER RESEARCH}

1. Replicate the study in other parts of the country using a large population, different sampling procedure, different research design and different research instruments of collecting data than the one used in the study. 
2. Studies may be carried out to establish how other social correlated namely social factors, pupils' attitude towards education and cultural factors jointly or separately affects pupils transition rates from public primary to secondary schools.

\section{REFERENCES}

Alderman, H. \&Paterno, E.M. (2009), school quality, school cost and the public/private school choice of Low-Income Households in Pakistan, Journal of Human Resources 34,304326.

Byrnes, V. \& Balfanz, R. (2012). Chronic Absenteeism; summarizing what we know from National Available Data. Baltimore; Johns Hopkins University.

Charles, K.O. (2013). The impact of student socialeconomic background on Academic performances in Universities, a case of students in Kisii University College. America international Journal of Social Science, vol 2. No 2 .

Chimombo, J.P. (2009). Issues in basic education in developing countries, an exploration of Policy of option for improved delivery. Journal of International Co-operation in Education vol8 No 1.

Creswell, J. W. (2009). Research Design: qualitative, quantitative and mixed methods approaches. Thousand Oaks, California: Sage Publications.

Dalton C. \& Glauber, R. (2009). Parental education involvements and children's Academic Risk. Estimate of the impact Sibship Size and Birth order from Exogenous variety in Fertility. National Bureau of Economic Research (NBER) working paper 11302.

Dermir, E.C. (2009). Factors influencing the academic achievement of the Turkish urban poor. International Journal of Educational Development. 29 (1), 17-29.

Dominic, M.K. (2013)." Factors influencing transition of pupils from primary to secondary schools in Meru Central District in Kenya”.
Med Thesis University of Nairobi. Unpublished.

Kaburu, L.R (2013). "Establishing barriers in transition from Primary to Secondary in Meru West Division, Meru County." Med Thesis Kenyatta University. Unpublished.

Kikechi, R.W \& Geoffrey, M. (2011). "Factors affecting transition rates from primary to Secondary Schools; case study Kenya "Masinde Muliro University of Science and Technology, (MMUST), Kenya. Unpublished.

Lewin, K.M (2008). Expanding access to Secondary schooling in Sub-Saharan African. Key Planning and finance issues. Create pathways to access Research Monograph No.8 Brighton University of Sussex.

Madassir, I.U, \& Norsuhaily, B.A. (2015). The impact of parents' occupation on academic performances of secondary school students in Kuala Terengganu. Multilingual Academic Journal on Education and Social Science. Vol 3 No 1

MOE, (2008). Report on Task Force on Affordable Secondary Education. Nairobi; Shren Pub. Ltd.

Ogola, J.O (2013). "Factors influencing transition rate of learners from primary to secondary schools in Rangwe division of Homa Bay District, Kenya". Med Thesis University of Nairobi- Unpublished.

Orodho, J.A (2009), Techniques for writing Research proposal and reports. New York: Prentice Hall

Oyango, B. (2013). Some Kenyan Children Are not in School Despite Free Primary Education.

Shafiqul, A. (2015). Effects of community factors on primary school learners' achievement in Rural Banglasesh.

Tomno, C. S. (2014). Teachers' Perception of Principals' Instructional Leadership Practices and their Influence on Students' Academic Achievement in Public Secondary Schools (Doctoral dissertation, Moi University). 
UNESCO, (2014). Textbook and learning resources; A Global and Framework for Policy Development. Paris: France.

UNICEF, (2016), "Defining quality in education" working paper series UNICEF; New York.

Vellymallay-Suresh, (2012). Parental involvement at home; analyzing the influences of parents' social-economic status, studies sociology of science vol.3 No1.

World Bank, (2008), Transition to Secondary Education in Sub-Saharah African Equity and Efficiency Issues. Working paper No 125, World Bank, Washington DC. 